\title{
Editorial
}

\section{The German Tax Reform 1994 and Its Turbulences}

\author{
Helmut Becker, Deloitte \& Touche, Düsseldorf
}

On 9 July 1993 the Federal Council (Bundesrat, representing the German States) passed the German Location Improvement Act which finally presents the tax reform 1994 in Germany that has already been desired for especially by international operating companies which were mainly interested in a reduction of the German tax burden.

Short time after the Tax Reform Act 1990 respectively 1992 has been passed, it became evident that a further tax reform would be necessary in order to solve the remaining tax problems. Therefore, the Minister of Finance promised to prepare a new tax reform as quickly as possible. However, which efforts are combined today with paving the way for a tax reform reveals, among others, the stringent legislation process.

Already in the year 1992 the Federal Minister of Finance Waigel presented a tax reform proposal named 'Standortsicherungsgesetz' (German Location Improvement Act). The draft's purpose was to reduce the competitive distortion of the German tax system in the European market and to increase the attractivity of Germany as an economic location both for domestic and foreign investors.

In order to pass the German Location Improvement Act as soon as possible and to clarify any objections already in advance, working groups were founded including representatives of industry and the leading trade associations. However, an acceleration of the legislation procedure could - due to colliding interests - not be attained thereby. Many formulation proposals have been elaborated and repealed again. Nevertheless, the draft prepared after all discussions should have been passed already on 18 June 1993; The Federal Council, however, refused the draft of the German Location Improvement Act. As a result, the Federal Minister of Finance opened a joint committee procedure between the German Federal Parliament (Bundestag) and the Federal Council (Bundesrat). The joint committee prepared a new draft proposition that has been presented for decision to the Federal Government. On 9 July 1993 the German Location Improvement Act could finally overcome all obstacles that opposed it and was passed both by the Federal Parliament and the Federal Council.

The basic elements especially relevant for the international taxation of the German Location Improvement Act can be summarized as follows:

- Reduction of the German income tax rate for business profits from 53 per cent to 47 per cent. The reduction applies only to profits effectively connected with trade and business and not for other income sources for which the tax rate is still 53 per cent.

- Reduction of the corporate income tax rate for accumulated profits from 50 per cent to 45 per cent.

- Reduction of the corporate income tax rate for distributed profits from 36 per cent to 30 per cent.

- Reduction of the corporate income tax rate for German permanent establishments and branches of foreign companies from 46 per cent to 42 per cent.

- Corporate income tax will no longer be imposed on dividends received by the German parent company from its foreign subsidiary if the German parent distributes these foreign source income to its shareholders.

Since the reduction of the considerable decreased tax rates shall be balanced, financial counter measures to approximately the same extent have been taken already. These especially include the following measures:

- Thin capitalization rules for shareholder debt financing with the following exemptions:

- debt/equity ratio $0.5: 1$

especially for profit/turnover-orientated loans and silent partnerships;

- debt/equity ratio of $3: 1$

for interest agreed as a fixed fraction of the loan capital; 
- special regulations are applicable for companies which do not qualify as a holding but hold participations as a business asset.

- However, not implemented by the German Location Improvement Act was the planned tax credit for a German parent company and its German shareholders for the foreign corporation income tax in case of a dividend distribution of foreign subsidiaries. This, however, is still under discussion.

The German Location Improvement Act can be seen as a first step in the right direction. Low tax rates will - especially by foreign investors - considered as signals that Germany is a favourable location for investments. However, this judgment does not consider that beside the tax rates, the determination and computation of profit have an important impact on the tax burden as well. In this context it is advantageous that the planned reduction of the declining-balance tax depreciation has not been realized.

Nevertheless further steps have to follow in order to increase Germany's attractivity in the international environment both for domestic and foreign entrepreneurs. Already now it can be stated that not all provisions of the German Location Improvement Act are of advantage but also constitute an additional tax burden. The complexity of the tax law was increased once again. A further tax reform will be necessary taking into account - among others - the imputation of foreign taxes. 